\title{
PENGARUH POLA ASUH ORANG TUA TERHADAP KENAKALAN REMAJA
}

\author{
Savitri Suryandari \\ Program Studi Pendidikan Guru Sekolah Dasar \\ Fakultas Bahasa dan Sains Universitas Wijaya Kusuma Surabaya \\ Email: savitri.suryandari69@gmail.com
}

Diterima: 11 Januari 2020 , Direvisi: 15 Januari 2020, Diterbitkan: 31 Januari 2020

\begin{abstract}
Juvenile delinquency at this time has occurated in almost all corner of the country. Factors tha influence that influence delinquency in adolescents one of them due parenting from parents. Forms of juvenile diliquency can be catagorized into ordinary diliquency, delingquency that leads to violation and crime or crime and crime or crime or crime and dilenquency that is spsecific. The characteristic that occur in naughty adolescence include difference in intelligence structure, physical and psychological differences as well as personality diffences consist of authoritarian parenting, authoritative parenthing, permissive parenting and neglect parenting. The result of this study are to determine the effect of parenting parents on juvenile deliquency and how to overcome them.
\end{abstract}

Keywords: parenting style, juvenile delinquency

\begin{abstract}
Abstrak: Kenakalan Remaja pada saat ini sudah terjadi hampir diseluruh pelosok tanah air, Faktor-faktor yang mempengaruhi kenakalan pada remaja salah satu nya pola asuh dari orang tua. Bentuk kenakalan remaja dapat di katagorikan menjadi kenakalan biasa, kenakalan yang menjurus pelanggaran dan kejahatan atau kriminal dan kenakalan yang bersifat khusus. Adapun karakteristik yang terjadi pada remaja nakal meliputi perbedaan struktur intelegensi, perbedaan fisik dan psikis serta perbedaan kepribadian. Pola asuh orang tua terdiri dari pola asuh Authoritarian, pola asuh Authoritative, pola asuh permisif serta pola asuh penelantaran. Hasil kajian ini untuk mengetahui pengaruh pola asuh orang tua terhadap kenakalan remaja dan bagaimana cara mengatasinya.
\end{abstract}

Kata Kunci : Pola Asuh orang tua, Kenakalan Remaja.

\section{PENDAHULUAN}

Masa Remaja merupakan salah satu periode perkembangan manusia yang paling penting dalam kehidupan setiap manusia. Suatu masa yang indah penuh dengan dengan segala suka cita, keunikkan, keceriaan dan menyenangkan. Hampir tidak ada manusia yang dapat melupakan masa- masa remaja yang dilaluinya, baik masa-masa yang menyenangkan maupun masa yang menyedihkan, tetapi tidak semua remaja dapat melalui masa tersebut dengan selamat dan bahagia menuju masa berikutnya.

Menurut Hurlock (1994) masa ini disebut sebagai masa topan badai atau strom and stress, Suatu masa dimana terdapat ketegangan emosional meninggi akibat dari perubahan fisik dan kelenjar dari remaja itu sendiri. Meningginya emosi karena remaja berada dibawah tekanantekanan sosial dan menghadapi kondisi baru sesuai dengan perkembangan fisik dan psikisnya.

Akibatnya muncul berbagai masalah yang dapat menghambat perkembangan pribadinya. Oleh karena itu, pada masa remaja mereka tidak menemukan identitas diri. Akibatnya banyak kenakalan yang dilakukan oleh remaja dari kenakalan yang sifatnya ringan sampai dengan perbuatan yang melawan hukum.

Menurut Kartono (1992), kenakalan remaja disebut sebagai Juvenille Delinquency, adalah perilaku jahat atau dursila, atau kejahatan atau kenakalan anak-anak muda, merupakan gejala sakit ( patologis ) secara sosial pada anakanak dan remaja yang disebabkan oleh bentuk 
pengabaian sosial, sehingga mereka itu mengembangkan bentuk tingkah laku yang menyimpang. Kenakalan remaja mengacu pada suatu rentang yang luas, dari tingkah laku yang tidak dapat diterima secara sosial sampai pelanggaran status hingga tindak kriminal.

Kapolda Metro Jaya Irjen Puput Bayu Seno Ajiseno mengatakan bahwa terjadi peningkatan kenakalan remaja sebanyak 11 kasus atau 36,66\% di tahun di tahun 2012. Total kasus kenakalan remaja terjadi selama 2012 mencapai 41 kasus, sementara pada tahun 2011 hanya 30 kasus ( Http://news.detik.com). Situs Badan Kependudukan dan Keluarga Berencana Nasional (BKKBN) memberitakan bahwa dari 2,4 juta kasus aborsi, 700.000 hingga 800.000pelakunya adalah remaja. Penelitian yang dilakukan oleh Badan Narkotika Nasional (BNN) dan Universitas Indonesia (UI) juga menemukan bahwa jumlah pengguna narkoba sebesar $1,5 \%$ dari populasi remaja Indonesia yang mencapai $30 \%$ dari jumlah penduduk Indonesia atau 3,2 juta orang (http://ntb.bkkbn.go.id). Berdasarkan data kasus tawuran pelajar 2012 di wilyah hukum Polda Metro Jaya, sudah terjadi puluhan kasus tawuran pelajan yang menimbulkan korbal luka dan meninggal dunia(http://metro.news.viva.co.id) dalam (Fatimah \& Umuri, 2014).

Kabid Pengembangan Kapasitas Satpol PP Surabaya, Deny C. Tupamahu menuturkan, mulai Januari hingga 22 November 2016, total kenakalan remaja di Surabaya yang di jumpai satpol PP sebanyak 793 kasus. Rinciannya, 597 laki-laki dan 196 perempuan. Angka ini mengalami peningkatan jika dibandingkan tahun lalu sebanyak 675 kasus ( Soerabaja News week.com, 2016 ).

Demikian perkembangan angka kenakalan remaja di Indonesia dari tahun ke tahun mengalami peningkatan jumlah serta macamnya, tidak hanya terjadi di Jakarta tapi juga terjadi di semua kota-kota yang ada di Indonesia.

Selain faktor internal yang dapat menyebabkan kenakalan remaja adapula faktor eksternal, salah satunya adalah faktor keluarga. Menurut (Gunarsa, 2004), Keluarga adalah unit sosial yang paling kecil dalam masyarakat yang perannya besar sekali terhadap perkembangan sosial, terlebih pada awal-awal perkembangannya yang menjadi landasan bagi perkembangan kepribadian selanjutnya.

Semua anak sangat membutuhkan kasih sayang, baik dari orang tua, guru, teman-teman sebaya dan orang-orang yang berada di sekitarnya. Seorang anak yang mendapatkan kasih sayang akan senang, betah, dan bahagia berada di dalam kelas serta memiliki motivasi untuk berpartisipasi aktif dalam kegiatan belajar mengajar. Sebaliknya, seorang anak yang merasa kurang mendapatkan kasih sayang, akan merasa terisolasi, rendah diri, merasa tidak nyaman, sedih gelisah, bahkan mungkin akan mengalami kesulitan belajar, serta memicu munculnya tingkah laku mal adaptif (Desmita, 2011).

Gaya pengasuhan atau pola asuh orang tua telah dianalisa secara luas sebagai penyumbang kenakalan remaja (Ryan D.S \& Thomas J.M, 2012). Orang tua jelas berperan besar dalam perkembangan kepribadian anak. Orang tua menjadi faktor penting dalam menanamkan dasar kepribadian yang ikut menentukan corak dan gambar kepribadian seseorang setelah dewasa (Gunarsa, 2004).

Menurut penelitian Masngudin (2001), salah satu sebab kenakalan pada remaja adalah sikap orang tua dalam mendidik anaknya. Dalam kaitannya dengan keberfungsian sosial keluarga secara positif dan adaptif bagi keluarga yaitu jika berhasil dalam melaksanakan tugas-tugas kehidupan, peranan, dan fungsinya serta mampu memenuhi kebutuhannya.

Sikap orang tua dalam mendidik anak diartikan sebagai pola asuh orang tua dalam mendidik anaknya, menurut Baumrind 1967 (dalam Santrock, 2007), terdapat empat pola asuh orang tua yaitu, Pola asuh Authoritative, Pola asuh Authoritarian, Pola asuh Permisif serta Pola asuh penelantaran.

Berdasarkan uraian diatas, terlihat betapa pentingnya masalah pola asuh bagi remaja pada umumnya, Di karenakan remaja adalah harapan bangsa di masa yang akan mendatang, dan pada diri merekalah harapan bangsa diletakkan, Oleh karena itu sangat penting kiranya untuk mengetahui informasi tentang seluk beluk kenakalan remaja dan faktorfaktor yang mempengaruhinya.

\section{PENGERTIAN REMAJA}

Istilah adolescence atau remaja dari kata lain adolescere atau kata bendanya adolescentia yang berarti remaja. Dalam arti tumbuh atau tumbuh menjadi dewasa (Hurlock, 1994). Menurut Madan (1995), menyebut masa remaja sebagai masa baliq atau masa puber, masa baliq adalah batasan usia ketika seorang remaja sudah mampu melakukan fungsi reproduksi, ditandai 
dengan pertumbuhan kelenjar seks pada remaja putra dan putri serta kemampuan melakukan fungsi seksual secara sempurna. Sedangkan masa puber adalah masa transisi individu dari masa kanak-kanak menuju masa dewasa.

Menurut Hurlock dalam (Desmita, 2011), Fase Adolescence (remaja), mulai usia 11 dan 13 tahun sampai usia 21 tahun, yang terbagi atas tiga masa yaitu : (a). Fase pre adolescence: mulai usia 11 - 13 tahun untuk wanita dan usia sekitar setahun kemudian bagi pria, (b). Fase early adolencence: mulai $13-14$ tahun sampai 16 - 17 tahun, (C). Fase late adolescence: masamasa akhir dari perkembangan seseorang atau hampir bersamaan dengan masa ketika seseorang tengan menempuh perguruan tinggi.

\section{KARAKTERISTIK ANAK USIA REMAJA}

Ciri yang menonjol dalam masa ini adalah individu mengalami pertumbuhan dan perkembangan yang sangat pesat baik fisik, emosional dan sosial. Menurut ( Hurlock, 1994 ), Pada masa remaja ini ada beberapa perubahan yang universal yaitu meningkatknya emosi, perubahan fisik, perubahan pada minat dan peran, perubahan perilaku, nilai-nilai sikap ambivalen terhadap setiap perubahan.

Menurut ( Desmita, 2011 ), Masa remaja ( 12 - 21 tahun ) merupakan masa peralihan antara anak-anak dan masa kehidupan orang dewasa. Masa remaja sering dikenal dengan masa pencarian jati diri ( ego identity). Masa remaja di tandai dengan sejumlah karakteristik penting, yaitu :

1. Mencapai hubungan yang matang dengan teman sebaya.

2. Dapat menerima dan belajar peran sosial sebagai pria atau wanita dewasa lainnya.

3. Menerima keadaan fisik dan mampu menggunakan secara efektif.

4. Mencapai kemandirian emosional dari orang tua dan orang dewasa lainnya.

5. Memilih dan mempersiapkan karier di masa depan sesuai dengan minat dan kemampuannya.

6. Mengembangkan sikap positif terhadap pernikahan, hidup berkeluarga dan memiliki anak.

7. Mengembangkan ketrampilan intelektual dan konsep-konsep yang diperlukan sebagai warganegara.

8. Mencapai tingkah laku yang bertanggung jawab secara sosial.
9. Memperoleh seperangkat nilai dan sistem etika sebagai pedoman dalam bertingkah laku.

10. Mengembangkan wawasan keagamaan dan meningkatkan religiusitas.

Menurut Kartono (1992), karakteristik umum yang terjadi pada remaja nakal dan remaja tidak nakal, perbedaan itu mencakup:

1. Perbedaan struktur Intelektual

Pada umumnya intelegensi mereka tidak berbeda dengan intelegensi remaja normal, namun jelas terdapat fungsi-fungsi kognitif khusus yang berbeda. Biasanya kenakalan remaja ini mendapatkan nilai-nilai lebih tinggi untuk tugas-tugas prestasi dari pada bidang ketrampilan verbal ( tes Wechsler).

\section{Perbedaan fisik dan psikis}

Remaja yang nakal lebih "idiot secara moral" dan memiliki perbedaan ciri karakteristik yang jasmani sejak lahir jika dibandingkan dengan remaja normal.Bentuk tubuh mereka lebih kekar, berotot, kuat dan pada umumnya bersikap lebih agresif. Hasil penelitian juga menunjukkan ditemukannya fungsi fisiologis dan neurologis yang khas pada remaja nakal, mereka kurang beraksi terhadap stimulus kesakitan dan menunjukkan ketidak matangan jasmaniah atau anomali perkembangan tertentu.

3. Perbedaan kepribadian

Remaja nakal mempunyai sifat kepribadian khusus yang menyimpang seperti :

a. Hampir semua remaja nakal hanya berorientasi pada masa sekarang, bersenang-senang dan puas pada hari ini. Mereka tidak mampu membuat rencana bagi masa depan.

b. Kebanyakan mereka terganggu secara emosional.

c. Mereka kurang bersosialisasi dengan masyarakat normal, sehingga tidak mampu mengenal norma-norma kesusilan, dan tidak bertanggung jawab secara sosial.

d. Mereka senang menceburkan diri dalam kegiatan tanpa pikir panjang yang merangsang kejantanan, walaupuan mereka menyadari besarnya resiko dan bahaya yang terkandung.

e. Pada umumnya mereka sangat impulsif dan suka menyerempet bahaya.

f. Hati nurani tidak atau kurang lancar fungsinya. 
g. Mereka kurang memiliki disiplin diri dan kontrol diri, sebab mereka memang tidak pernah dituntun atau di didik untuk melakukan hal tersebut. Tanpa pengekangan diri itu mereka menjadi liar, ganas, tidak bisa dikuasai oleh orang dewasa. Muncullah kemudian kebiasaan jahat yang mendarah daging dan kemudian menjadi stigma.

Dari uraian diatas dapat disimpulkan bahwa remaja nakal biasanya berbeda dengan remaja tidak nakal. Remaja nakal biasanya lebih ambivalen terhadap otoritas, percaya diri, pemberontak, mempunyai kontrol diri yang kurang, tidak mempunyai orientasi pada masa depan dan kurangnya ketamakkan sosial, sehingga sulit bagi mereka untuk menyesuaikan diri dengan lingkungan sosial.

\section{PENGERTIAN DAN MOTIF KENAKALAN REMAJA}

Kenakalan remaja sebagai tingkah laku yang menyimpang dari norma-norma hukum pidana (Sarwono, 2008). Selain itu Santrock (2003), juga menambahkan kenakalan remaja sebagai kumpulan dari berbagai perilaku, dari perilaku yang tidak dapat diterima secara sosial sampai tindakan kriminal.

Willis (2012) mengungkapkan bahwa kenakalan remaja ialah tindak perbuatan sebagaian para remaja yang bertentangan dengan hukam, agama dan norma-norma masyarakat, sehingga akibatnya dapat merugikan orang lain, mengganggu ketentraman dan juga merusak dirinya sendiri.

Dari pendapat di atas dapat disimpulkan bahwa kecenderungan kenakalan remaja adalah kecenderungan remaja untuk melakukan tindakan melanggar aturan yang dapat mengakibatkan kerugian dan kerusakan baik terhadap diri sendiri maupun orang lain, yang perilaku tersebut tidak dapat diterima secara sosial oleh masyarakat dinilai suatu kelainan yang disebut kenakalan, maupun tindak kriminal.

Menurut Kartono (1992), motif atau penyebab yang mendorong para remaja melakukan tindak kejahatan dan dursila itu antara lain :
a. Untuk memuaskan kecenderungan keserakahan.
b. Meningkatnya agresivitas dan dorongan seksual.
c. Salah asuh dan salah didik orang tua.

d. Hasrat untuk berkumpul dengan kawan senasib dan sebaya.

e. Kecenderungan pembawaan yang patologis atau abnormal.

f. Konflik batin sendiri.

\section{BENTUK-BENTUK REMAJA}

KENAKALAN

Kenakalan Remaja mempunyai bentuk atau wujud pelilaku deliquents, menurut Gunarso (2004), mengatakan dari segi hukum kenakalan remaja di golongkan dalam dua kelompok yang berkaitan dengan norma-norma hukum yaitu : a. Kenakalan yang bersifat amoral dan sosial serta tidak diatur dalam undang-undang sehingga dapat atau sulit digolongkan sebagai pelanggaran hukum; b. Kenakalan yang bersifat yang melanggar hukum dengan penyelesaian sesuai dengan undang-undang dan hukum yang berlaku sama dengan perbuatan melanggar hukum.

Bentuk kenakalan remaja dapat dikatagorikan menjadi tiga katagori (Masngudin, 2004), yaitu : a. Katagori kenakalan biasa, b. Katagori kenakalan remaja yang menjurus pada pelanggaran dan kejahatan atau kriminalisai, c. Katagori yang bersifat khusus.

Sedangkan menurut Adler (1952) dalam (Kartono, 1992), bentuk dari kenakalan remaja atau perilaku diliquen :

a. Kebut-kebutan dijalanan yang mengganggu keamanan lalu lintas, dan membahayakan jiwa sendiri serta orang lan.

b. Perilaku ugal-ugalan, brandalan, urakan yang mengacaukan ketentraman milieu sekitar.

c. Perkelahian antar geng, antar kelompok, antar sekolah, antar suku

tawuran ), sehingga kadang-kadang membawa korban jiwa.

d. Membolos sekolah lalu menggelandang sepanjang jalan, atau sembunyi di tempat-tempat terpencil sambil melakukan ekperimen bermacammacam kedurjanaan dan tindak a-susila.

e. Kriminalitas anak, remaja dan adolencence antara lain berupa perbuatan mengancam, intimidasi, memeras, maling, mencuri, mencopet, merampas, menjambret, menyerang, merampok, menggarong, melakukan tindakan pembunuhan dengan jalan menyembelih korbanya, mencekik, 
meracun, tindak kekerasan dan pelanggaran lainnya.

f. Berpesta pora sambil mabukmabukkan, melakukan hubungan seks bebas, mabuk-mabukkan yang mengganggu lingkungannya.

g. Perkosaan, agresivitas seksual dan pembunuhan dengan motif seksual, atau di dorong oleh reaksi-reaksi kompensantoris inferior, menuntut pengakuan diri, depresi hebat, rasa kesunyian, emosi balas dendam, kekecewaan ditolak cintanya oleh seorang wanita, dan lain-lain.

h. Kecanduan dan ketagihan bahan narkoba yang erat bergandengan dengan tindak kejahatan.

i. Homoseksualitas, erotisme anal dan oral dan gangguan seksual lainnya pada remaja disertai tindak sadistis.

j. Perjudian dan bentuk-bentuk permainan lain dengan taruhan, sehingga mengakibatkan ekses kriminal.

k. Komersialisasi seks, pengguguran janin oleh gadi-gadis delikuen, dan pembunuhan bayi oleh ibu-ibu yang tidak menikah.

1. Tindakan radikal dan ekstrim, dengan cara kekerasan, penculikkan dan pembunuhan yang dilakukan oleh anakanak remaja.

m. Perbuatan a-sosial dan anti-sosial lain disebabkan oleh gangguan kejiwaan pada anak-anak dan remaja psikopatik, neurotik dan menderita gangguangangguan jiwa lainnya.

n. Tindakan kejahatan disebabkan oelh penyakit tidur ( encephlais lethargical), dan ledakan meningitis serta postencephalitic, juga luka di kepala dengan kerusakan pada otak adakalanya membuahkan kerusakan mental, sehingga orang yang bersangkutan tidak mampu melakukan kontrol diri.

o. Penyimpangan tingkah laku disebabkan oleh kerusakan pada karakter anak yang menuntut kompensasi, disebabkan adanya organ-organ yang inferior.

\section{PENGERTIAN POLA ASUH ORANG TUA}

Pola asuh orang tua dalam keluarga merupakan hal yang terpenting dalam pembentukan kepribadian anak. Dengan adanya sebuah pola asuh, orang tua dapat mendidik, membimbing dan mengarahkan serta mengawasi anak-anak mereka dalam bertindak dan bersikap agar tidak melakukan perbuatan yang negatif seperti kenakalan remaja.

Menurut Lestari.S (2012), Pola asuh orang tua adalah perilaku pengasuhan dengan muatan tertentu dan memiliki tujuan sosialisasi. Dengan kata lain, praktik pengasuhan (Parenting Practice) dapat di konseptualkan sebagai sistem interelasi yang dinamis yang mencakup pemantauan, pengelolaan perilaku, dan kognisi sosial dengan kualitas relasi orang tua - anak sebagai pondasinya.

Pola Asuh telah memberikan mana gaya pengasuhan yang yang efektif dan kurang efektif untuk mengajari dan mendorong anak-anak dan remaja mengembangkan sikap dan perilaku yang lebih prososial ( Johnson, AS, 2016 ).

\section{MACAM-MACAM POLA ASUH ORANG TUA}

Menurut Diana Baumrind dalam Santrcok, J.W (2007), terdapat macam-macam Pola asuh orang tua, yaitu :

a. Pengasuhan Authoritarian atau Otoriter adalah gaya pengasuhan yang membatasi atau menghukum. Dimana orang tua mendesak anak untuk mengikuti arahan mereka dan menghormati pekerjaan dan upaya mereka. Orang tua yang otoriter menerapkan batas dan kendali yang tegas dan meminimalisasi perbedaan verbal. Orang tua otoriter cenderung sering memukul anak, memaksakan aturan secara kaku tanpa menjelaskanya, dan menujukkan amarah kepada anak. Anak dari orang tua yang otoriter seringkali tidak bahagia, katakutan dan minder ketika membandingkan diri dengan orang lain, tidak mampu memulai aktivitas dan memiliki kemampuan komunikasi yang lemah. Anak dari orang tua yang otoriter cenderung berperilaku agresif.

b. Pengasuhan Authoritatif atau Demokratikmendorong anak untuk mandiri namun masih menerapkan batas kendali pada tindakan mereka.Tindakan verbal memberi dan menerima dimungkinkan, dan orang tua bersikap sangat hangat dan penyayang pada anak. Orang tua Otoritatif menunjukkan kesenangan dan dukungan sebagai respon terhadap perilaku konstruktif anak. Mereka juga mengharapkan perilaku anak yang dewasa, mandiri sesuai dengan usianya. Anak yang memiliki orang tua otoritatif seringkali ceria, bisa mengendalikan diri dan mandiri, dan berorientasi pada prestasi. 
Mereka cenderung untuk mempertahankan hubungan yang ramah dengan teman sebaya, bekerja sama dengan orang dewasa, dan bisa mengatasi stres dengan baik.

c. Pengasuhan yang menuruti atau Permisif adalah gaya pengasuhan dimana orang tua sangat terlibat dengan anak, namun terlalu menuntut atau mengontrol mereka. Orang tua semacam ini membiarkan anak melakukan apa yang ia inginkan. Hasilnya, anak tidak pernah belajar mengendalikan keinginannya. Beberapa orang tua sengaja membesarkan anak mereka dengan cara ini karena mereka percaya bahwa kombinasi antara keterlibatan yang hangat dan sedikit batasan akan menghasilkan anak yang kreatif dan percaya diri. Namun anak yang memiliki orang tua yang selalu menurutinya, jarang belajar menghormati orang lain dan mengalami kesulitan untuk megendalikan perilakunya. Mereka mungkin mendominasi, egosentris, tidak menuruti aturan, dan kesulitan dalam hubungan dengan teman sebaya.

d. Pengasuhan yang mengabaikan adalah gaya di mana orang tua sangat tidak terlibat dalam kehidupan anak. Anak yang memiliki orang tua yang mengabaikan merasa bahwa aspek lain kehidupan orang tua lebih penting dari pada diri mereka. Anak-anak ini cenderung tidak memiliki kemampuan sosial. Banyak diantaranya memiliki pengendalian diri yang buruk dan tidak mandiri. Mereka sering kali memiliki harga diri yang rendah, tidak dewasa dan cenderung terasing dari keluarga. Dalam masa remaja, mereka mungkin menunjukkan sikap membolos dan nakal.

\section{HASIL PENELITIAN DAN PEMBAHASAN}

Penelitian yang dilakukan oleh Ana Stevi, dkk (2017), pada 30 remaja di Desa Bulude Selatan Kabupaten Talaud, menunjukkan terdapat hubungan antara pola asuh permisif orang tua dengan perilaku mengkonsumsi alkohol pada anak usia remaja di Desa Bulude Selatan Kabupaten Talaud. Demikian juga Menurut Luthfiah Nur Aini ( 2011 ), penelitian di lakukan dengan sample 40 remaja di RW V kelurahan Sidokare Kecamatan Sidoarjo Kabupaten Sidoarjo , menunjukkan sebagian besar remaja di asuh dengan pola asuh otoriter, sehingga cenderung mempegaruhi kenakalan remaja yang ada di RW V kelurahan Sidokare Kecamatan Sidoarjo Kabupaten Sidoarjo, dimana semakin tinggi tingkat pola asuh orang tua otoriter, maka tingkat kenakalan remaja juga semakin tinggi.

Tanusree, dkk (2010), melakukan penelitian pada 200 remaja berusia $11-18$ tahun di India, (100 anak diliquents dan 100 anak non-deliquents), menunjukkan pola asuh authoritative adalah pola asuh yang terbaik, sedangkan pola asuh penelantaran dan authoritarian berhubungan positif dengan kenakalan remaja.

\section{KESIMPULAN}

Pada dasarnya kenakalan remaja menunjuk pada suatu bentuk perilaku remaja yang tidak sesuai dengan norma-norma yang hidup di dalam masyarakat. Cara- cara yang di gunakan orang tua dalam mendidik anak dengan cara berperan sebagai pembimbing, berperan sebagai teladan bagi putra putrinya.

Pola asuh atau gaya pengasuhan dari orang tua sangat menentukan bagaimana remaja berperilaku dan bersikap dalam kehidupannya. Beberapa faktor yang diprediksi menyebabkan kriminalitas pada remaja adalah pola asuh permisif dan otoriter, dimana terjadi pengasuhan yang buruk dan kenegatifan emosional seperti adanya permusuhan, penolakan, lemahnya pengawasan, disiplin yang tidak konsisten, ikatan orang tua-anak yang lemah, dan pengabaian hak dan keselamatan anak. (Scott A.J, 2016).

Dari pandangan diatas dapat disimpulkan bahwa gaya pengasuhan yang terbaik adalalah pola asuh Authoritatif atau demokratik dengan tambahan saran, agar orang tua memberikan:

1. Pendidikan agama yang lebih kuat dimulai sejak masa kecil.

2. Memberikan Reward dan Punisment sesuai dengan porsi perbuatan yang dilakukan oleh anak - anak,

3. Memberikan pendidikan yang menguatkan karakter kebangsaan, sehingga anak-anak tidak terjebak untuk menyukai budaya barat dari pada budaya negerinya sendiri.

\section{DAFTAR RUJUKAN}

Ana Stevi D, Franky O, Yolanda B. 2017. Hubungan Pola Asuh Permisif Orang Tua dengan perilaku mengkonsumsi Alkohol pada Anak Usia Remaja di Desa Balude Selatan Kabupaten 
Talaud. E-Jurnal Keperawatan ( e-KP ). Vol 5. No. 1.

Desmita. 2011. Psikologi Perkembangan Peserta didik, Panduan bagi orang tua dan Guru dalam Memahami Psikologi Anak usia SD, SMP, dan SMA. Bandung : PT Remaja Rosdakarya

Gunarsa, S. 2004. Psikologi Praktis: Anak, remaja dan keluarga. Jakarta : Gunung Mulia.

Hurlock, E. 1994. Psikologi Perkembangan: Suatu Pendekatan sepanjang rentang kehidupan. Edisi Kelima.Jakarta: Erlangga.

Kartono, K. 1992. Patologi Sosial II: Kenakalan Remaja. Jakarta : Rajawali Press

Luthfiah Nur Aini.2011.Hubungan Pola Asuh dengan Kenakalan Remaja di $R W V$ Kelurahan Sidokare Sidoarjo. Jurnal Keperawatan \& Kebidanan Stikes Dian Husada Mojokerto.

Madan, Y. 1995. Sex Education 4 Teen: Pendidikan Sex Remaja dalam Islam. Jakarta : Mizan Publika.

Masgudin, 2004. Kenakalan Remaja Sebagai Perilaku menyimpang Hubungannya dengan Keberfungsian Sosial Keluarga: Kasus di Pondok Indah Pinang Pinggiran Kota Metropolitan Jakarta. Badan Latbang Sosial Departemen Sosial. Diakses pada tanggal 15 November 2014 dari http://www.depsos.go.id/Balatbang/Pus litbang\%20UKS/2004/Masngudin.

Ryan D.S. \& Thomas J.M. 2012. Parenting Style Transition and Deliquency. Sage Journal.

Santrock, John.W. 2007. Child Development. Terjemahan Mila Rahmawati dkk, Perkembangan Anak. Jakarta: Erlangga.

Scoot A Johnson. 2016. Parenting Styles and Raising Delinquent Children: Responsibility of Parents in Encouraging Violent Behavior. Forensic Research \& Criminology International Journal. USA

Siti Fatimah \& M. Towil U. 2104. Faktor-faktor penyebab kenakalan remaja di desa Kemading Kecamatan Tanjung Sari Kabupaten Guning Kidul, Jurnal Citizenship, Vol.4, no. 1.

Sri Lestari. 2012. Psikologi Keluarga. Jakarta: Kencana www.surabayanewsweek.com/2016/11/kenakala $\mathrm{n}$ - remaja - surabaya - meningkat.

Willis, Sofyan. 2012, Remaja dan Masalahnya. Bandung: Alfabeta.

Sarwono, Sarlito.W. 2008. Psikologi Remaja. Jakarta : Raja Grafindo Persada.

Tanusree Moitra \& Indriani Mukherjee.2010. Does parenting behavior impact delinquency? A comparative study of deliquents and deliquents. International Journal of Criminal Justice Science. Vol. 5. India 